\title{
АНАЛІТИЧНЕ ЗАБЕЗПЕЧЕННЯ
} ДІЯЛЬНОСТІ БІЗНЕСУ

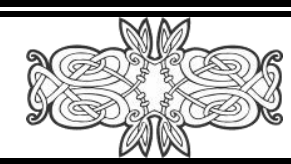

УДК 636.2.034.082:338.43(477)

JEL Classification 0130, L320, M110

\author{
Кругляк Ольга \\ к.е.Н., С.H.C., п.Н.C. \\ лабораторія економіки племінних ресурсів та дослідних господарств \\ Інститут розведення і генетики тварин імені М. В. Зубця НААН \\ с. Чубинське, Україна \\ E-mail: ovokrug@gmail.com
}

\section{АНАЛІТИЧНА ІНТЕРПРЕТАЦІЯ НЕПРОДУКТИВНИХ ВИТРАТ В ТВАРИННИЦТВІ}

\section{Анотація}

Bступ. Дослідження присвячене аналітичній інтерпретації непродуктивних витрат в тваринництві, зокрема, в молочному скотарстві та пошуку шляхів зниження рівня непродуктивних витрат на утримання великої рогатої худоби молочного напрямку.

Методологія. Інформаційною базою слугувала створена автором база даних з економічних показників діяльності державних підприємств Черкаської області, що входять до мережі Інституту розведення і генетики тварин імені М. В. Зубия НААН України. В процесі дослідження, для систематизації, класифікації та аналітичної інтерпретації непродуктивних витрат в тваринництві, загалом, та молочному скотарстві, зокрема застосовувались методи контент-аналізу наукових джерел та нормативно-правових документів, структурний аналіз і порівняння, статистичні та економіко-математичні методи.

Результати. В результаті досліджень здійснено класифікацію витрат за ефективністю в молочному скотарстві. Результати досліджень показали, що аналіз непродуктивних витрат на утримання великої рогатої худоби молочного напрямку продуктивності доцільно здійснювати на основі сукупності критеріїв, як-то: інноваційно-виробничі, ринкові, соціально-екологічні. Відповідно до пропонованих підходів здійснено аналітичну інтепретацію непродуктивних витрат на виробництво продукиії молочного скотарства в державних підпиємствах, що входять до мережі Інституту розведення і генетики тварин імені М. В. Зубия НААН (Черкаська обл.), частка яких склала близько 2 \% від витрат на виробництво молока.

Підтверджено гіпотезу, що непродуктивні витрати в молочному скотарстві виникають від незбалансованої годівлі, неефективного способу утримання, недостатнього догляду та ветеринарного забезпечення, зниження генетичного потенціалу, подовження тривалості міжотельного періоду, скорочення тривалості господарського використання корів, низької якості молока та нееквівалентних цін його реалізації.

Висновки. За результатами досліджень зроблено висновок, що пропоновані заходи щодо оптимізації виробничих витрат підприємств галузі молочного скотарства шляхом зниження рівня непродуктивних витрат на утримання великої рогатої худоби молочного напрямку продуктивності можливі за впровадження комплексу заходів із селекції, генетики, відтворення та годівлі тварин.

Ключові слова: виробничі витрати, аналіз, управління витратами, непродуктивні витрати, молочне скотарство, ефрективність.

\section{Вступ.}

Найважливіше значення в управлінні витратами відіграє оперативно отримана інформація про витрати, що дає змогу змогу втручатись у виробничий процес і оптимізувати його. Для ефективного управління витратами на підприємстві серед усіх видів витрат слід виділяти 
непродуктивні витрати і шукати шляхи їх зниження. Це обумовлює актуалізацію досліджень 3 аналізу та оптимізації рівня витрат підприємств аграрного сектору і $є$, на сьогодні, одним з ключових завдань економічних досліджень.

\section{Аналіз останніх досліджень і публікацій.}

У сучасній науковій літературі, присвяченій проблемам управління витратами підприємства загалом, а також питання обгрунтованого аналізу рівня витрат постійно перебуває у центрі уваги науковців. Над питаннями формування основних засад вивчення проблеми аналізу витрат виробництва у сільському господарстві працювали вітчизняні вчені В. Г. Андрійчук [2, 3], П. С. Березівський [4, 5], С...Дем'яненко [6], В. С. Дієсперов [7], В. Я. Месель-Веселяк [8, 9], П. Т. Саблук, В.І.Бойко, Т.Л.Мостенська [9-11], Н.В.Ульянченко, Д.В.Шиян [12] та ін., які визначили поняття витрат, обґрунтували їх класифікацію, методичні підходи до вартісного вираження витрат сільськогосподарського виробництва за видами спожитих ресурсів тощо.

Значна увага дослідників приділена впливу особливостей функціонування підприємств галузі тваринництва, зокрема молочного скотарства, де в якості специфічних засобів виробництва використовуються живі тварини, отже, біологічні фрактори мають суттєвий вплив на технологічний процес виробництва продукції цих галузей та склад і обсяг використаних ресурсів, а, відтак, продовження подальших досліджень оптимізації виробничих витрат підприємств галузі молочного скотарства є надзвичайно актуальним.

\section{Мета.}

Одним із найбільш ефективних підходів оптимізації виробничих витрат підприємств галузі молочного скотарства $€$ зниження рівня непродуктивних витрат на утримання великої рогатої худоби молочного напрямку продуктивності. За мету досліджень поставлено формування підходів до проведення економічної оцінки непродуктивних витрат на утримання великої рогатої худоби молочного напряму продуктивності.

\section{Методологія дослідження.}

В процесі дослідження застосовувались патентний пошук, контент-аналіз наукових джерел та нормативно-правових документів, структурний аналіз і синтез, порівняння, статистичні, економіко-математичні методи. Інформаційною базою слугували економічні показники роботи державних підприємств, що входять до мережі Інституту розведення і генетики тварин імені М.В. Зубця НААН (Черкаська обл.).

\section{Результати.}

За результатами досліджень облікової політики підприємств, що входять до що входять до мережі Інституту розведення і генетики тварин імені М. В. Зубця НААН витрати для цілей планування та обліку виділяються за статтями калькуляції собівартості. Зокрема, статтями витрат на виробництво продукції основного молочного стада $€$ - витрати на оплату праці разом із нарахованим єдиним соціальним внеском, корми, роботи та послуги, матеріальні витрати, що серед інших включають вартість палива та мастильних матеріалів, засоби захисту тварин, амортизація необоротних активів, витрати на ремонт необоротних активів та інші витрати на утримання основних засобів, інші витрати та загальновиробничі витрати [14].

На думку В.С. Леня та В.С.Мисіка, наведені види витрат, відповідно до доцільності їх витрачання, також поділяються на продуктивні та непродуктивні, інформація про останні має окремим рядком наводитись в Примітках до річної фрінансової звітності підприємства [15]. На відміну від продуктивних витрат, які $є$ виправданими та доцільними для даного виробництва, непродуктивні витрати виникають в разі порушень технології, недоліків в організації виробництва тощо.

До непродуктивних витрат, передусім, необхідно віднести витрати, що мають відхилення у 
порівнянні із нормативними, тобто незаплановані витрати, що не були відображені у кошторисі. Їх поділяють на непродуктивні витрати та непродуктивні втрати [15] (рис. 1).

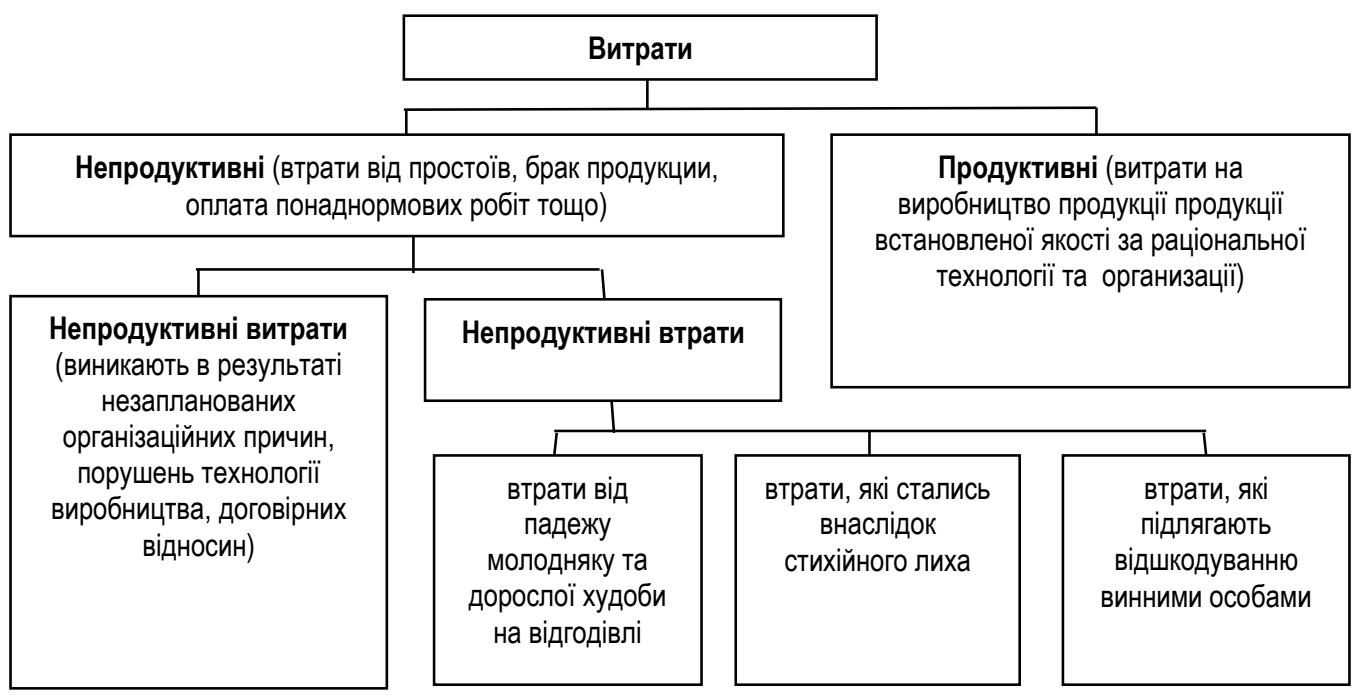

Рис. 1. Класифікація витрат за ефективністю в молочному скотарстві

Джерело: систематизовано автором на основі контент-аналізу наукових джерел [1,5,10-15]

Зокрема, втрати можуть виникати у випадку заподіяння матеріальної шкоди третіми особами (мають бути відшкодовані); знецінення запасів; втрати, пов'язані з надзвичайними подіями; у вигляді штрафів, пені, списання безнадійної заборгованості тощо. Для цілей бухгалтерського обліку до непродуктивних втрат в молочному скотарстві включають втрати від падежу молодняку та дорослої худоби на відгодівлі, за винятком втрат, які сталися внаслідок стихійного лиха, сум, що підлягають відшкодуванню винними особами, вартості одержаної сировини (шкур, технічного м'яса тощо) за цінами можливої реалізації [14].

Щодо непродуктивних витрат, що виникають внаслідок незапланованих організаційних причин, порушень технології виробництва, договірних відносин, - на відміну від непродуктивних втрат, їх можливо уникнути. Тому причини та динаміка їх виникнення мають бути об'єктом прискіпливого вивчення управлінського обліку та фінансового менеджменту підприємств. Серед наслідків порушення технології та недоліків організації виробництва в молочному скотарстві найчастіше зустрічаються:

- значна трудомісткість продукції та недостатня продуктивність праці;

- перевитрати матеріалів;

- перевитрати кормів внаслідок порушення технології їх заготівлі та зберігання, недостатнього нормування годівлі й балансування раціонів;

- порушення технології відтворення стада і вирощування ремонтного молодняку;

- несвоєчасна діагностика та лікування тварин;

- неефективне використання обладнання тваринницьких ферм.

Економічну оцінку непродуктивних витрат на утримання великої рогатої худоби в тваринництві, зокрема, молочного напрямку продуктивності, що утримується суб'єктами господарювання, необхідно здійснювати на основі критеріїв, що враховують основні фрактори впливу на ефрективність. До таких критеріїв відносять інноваційно-виробничі, ринкові, соціальноекологічні (рис. 2).

Основними напрямами впровадження інновацій у виробничі процеси племінного молочного 
скотарства наразі виступають:

- підвищення генетичного потенціалу тварин;

- раціональне використання кормових ресурсів, підвищення якості кормів;

- модернізація та автоматизація виробничих процесів;

- впровадження енергозберігаючих технологій [16].

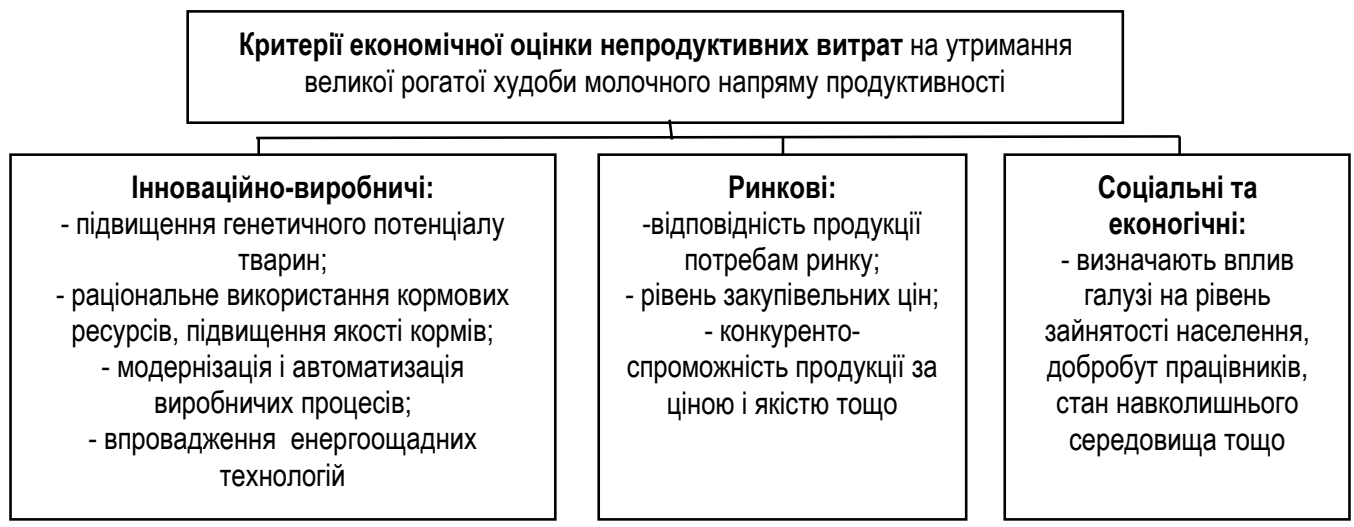

Рис. 2. Критерії економічної оцінки непродуктивних витрат в молочному скотарстві

Джерело: систематизовано автором на основі контент-аналізу наукових джерел

До ринкових критеріїв оцінювання витрат відносяться відповідність виробленої продукції потребам ринку, рівень закупівельних цін, конкурентоспроможність продукції за ціною та якістю та ін. Соціальні та екологічні критерії визначають вплив галузі на рівень зайнятості населення, стан навколишнього середовища тощо. Оцінка непродуктивних витрат за всіма критеріями відбувається із застосування прийомів економічного аналізу.

У період фінансової кризи, коли ділова активність падає й відповідно зменшуються обсяги споживання продукції скотарства і доходи від ії реалізації, для підприємств, що утримують тварин, скорочення витрат стає питанням виживання. Проте підходити до цього процесу потрібно обдумано, для того, щоб у результаті скорочення витрат не постраждали життєво важливі аспекти діяльності підприємства.

Для досягнення необхідного позитивного ефекту від скорочення витрат, необхідно:

- проаналізувати витрати;

- визначити серед них непродуктивні витрати, які слід скорочувати;

- виявити резерви підвищення дохідності виробництва;

- розробити та запровадити заходи щодо скорочення непродуктивних витрат.

Раціональне використання кормів - один 3 основних шляхів зміцнення економіки господарства. Для уникнення непродуктивних витрат необхідно дотримання всіх технологічних етапів виробництва, зберігання, роздавання та згодовування кормів. Резервами підвищення ефективності витрачання кормів $€$ підвищення рівня конверсії кормів у продукцію і зниження вартості раціону та окремих його складових частин. Зокрема, знаходження постачальників 3 меншими цінами на концентровані корми та замінники молока, вирощування кормових культур 3 більшою поживністю.

Важливе значення має також система та спосіб утримання тварин. Наприклад, при безприв'язному витрати на оплату праці на 67\% нижчі, ніж при прив'язному, рентабельність виробництва молока збільшується на 4\% [17].

Ефективність системи утримання та годівлі корів оцінюють за наявністю таких патологій як затримка плаценти (середнє значення на рівні 8\%; бажане - 5\%), клінічний післяродовий парез (3\%; 
1\%), клінічний кетоз (2\%; 0\%) [18]. Найбільше ж економічних втрат господарствам завдають захворювання молочної залози, що призводять до зниження рівня молочної продуктивності корів, якості молока; збільшення рівня захворюваності телят, вибракування худоби. Наразі сукупні непродуктивні витрати від захворювання вимені оцінюють у еквівалент 5-8\% валового річного надою [19], або від 2,8 до 4,5 тис. грн. на одну корову (табл. 1).

Таблиця 1

\section{Вплив кількості соматичних клітин на втрати молока*}

\begin{tabular}{|c|c|c|c|}
\hline \multirow{2}{*}{ Наявність соматичних клітин } & \multicolumn{3}{|c|}{$\begin{array}{c}\text { Втрати молока від 1 корови на рік } \\
\text { (продуктивність 7000-7200 кг) }\end{array}$} \\
\cline { 2 - 4 } & $\%$ & $\mathbf{~ к г ~}$ & грн. $^{* *}$ \\
\hline 50000 & 0 & 0 & 0 \\
\hline 100000 & 3 & 210 & 1680 \\
\hline 200000 & 6 & 420 & 3360 \\
\hline 300000 & 7 & 490 & 3920 \\
\hline 400000 & 8 & 560 & 4480 \\
\hline 500000 & 9 & 630 & 5040 \\
\hline 600000 & 10 & 700 & 5600 \\
\hline 700000 & 11 & 770 & 6160 \\
\hline 1000000 & 12 & 870 & 6960 \\
\hline
\end{tabular}

*-джерело: [19];

**- розраховано за поточних закупівельних цін на молоко (8,0 грн./ка молока першого гатунку)

До непродуктивних витрат на утримання великої рогатої худоби молочного напрямку продуктивності також можна віднести фінансові втрати від зниження генетичного потенціалу, подовження тривалості міжотельного періоду, скорочення тривалості господарського використання корів, нееквівалентних цін реалізації продукції галузі.

Відповідно до проведеного аналізу структури собівартості продукції скотарства в державних підприємствах «Дослідне господарство «Нива» та «Дослідне господарство «Христинівське», що входять до мережі Інституту розведення і генетики тварин імені М. В. Зубця НААН (Черкаська обл.), в структурі витрат на виробництво молока (табл. 2) найбільшу питому вагу становлять витрати на корми $(43,1 \%)$ та на оплату праці разом із нарахуваннями $(20,3 \%)$. У виробництві живої маси великої рогатої худоби (табл. 3) на корми та оплату праці припадає 78 \% всіх витрат.

Таблиия 2

Динаміка структури собівартості 1 ц молока в державних підприємствах дослідних господарствах мережі Інституту розведення і генетики тварин імені М. В. Зубця НААН, \%

\begin{tabular}{|c|c|c|c|c|c|c|c|c|}
\hline Елемент витрат & ్ㅜ & ํํํ & ஜั & ষ্ণ & $\stackrel{\text { ก }}{\frac{N}{2}}$ & ஸัণ & స̃⿱宀 & $\begin{array}{c}\text { Середнє за 2011- } \\
2017\end{array}$ \\
\hline Корми & 41,3 & 41,6 & 38,1 & 36,5 & 38,4 & 59,6 & 46,3 & 43,1 \\
\hline $\begin{array}{l}\text { Прямі витрати на оплату } \\
\text { праці разом } 3 \\
\text { відрахуваннями }\end{array}$ & 21,6 & 18,9 & 21,3 & 22,9 & 20,5 & 17,0 & 19,8 & 20,3 \\
\hline $\begin{array}{l}\text { Пальне і мастильні } \\
\text { матеріали }\end{array}$ & 2,1 & 3,7 & 4,4 & 4,4 & 3,7 & 3,2 & 3,9 & 3,6 \\
\hline $\begin{array}{l}\text { Амортизація необоротних } \\
\text { засобів }\end{array}$ & 2,4 & 2,0 & 0,8 & 4,2 & 1,9 & 0,5 & 0,6 & 1,8 \\
\hline $\begin{array}{l}\text { Решта матеріальних } \\
\text { витрат }\end{array}$ & 20,8 & 23,7 & 26,2 & 21,1 & 21,8 & 18,1 & 16,8 & 21,2 \\
\hline $\begin{array}{l}\text { Оплата послуг і робіт } \\
\text { сторонніх організацій }\end{array}$ & 8,9 & 7,5 & 5,4 & 4,8 & 8,9 & 1,5 & 10,4 & 6,8 \\
\hline $\begin{array}{l}\text { Решта інших прямих та } \\
\text { загально-виробничих } \\
\text { витрат }\end{array}$ & 2,9 & 2,6 & 3,8 & 6,1 & 4,8 & 0,1 & 2,2 & 3,2 \\
\hline
\end{tabular}


Джерело: розраховано автором на даних державних підприємств «Дослідне господарство «Нива» та «Дослідне господарство «Христинівське» Інституту розведення і генетики тварин імені М. В. Зубия НААН (Черкаська обл.)

\section{Динаміка структури собівартості 1 ц живої маси великої рогатої худоби в державних підприємствах дослідних господарствах мережі Інституту розведення і генетики тварин імені} M. В. Зубця НАAH, \%

\begin{tabular}{|c|c|c|c|c|c|c|c|c|}
\hline Елемент витрат & ז্ণ & $\stackrel{\text { กิ }}{\stackrel{2}{2}}$ & $\stackrel{m}{\stackrel{m}{2}}$ & 芒 & م) & ํํํ & స్ํำ & $\begin{array}{c}\text { Середнє за } \\
2011-2017\end{array}$ \\
\hline Корми & 55,1 & 63,1 & 59,4 & 68,0 & 52,0 & 54,7 & 70,1 & 60,3 \\
\hline $\begin{array}{l}\text { Прямі витрати на оплату праці разом } 3 \\
\text { відрахуваннями }\end{array}$ & 21,9 & 18,3 & 16,5 & 21,3 & 22,1 & 7,2 & 16,6 & 17,7 \\
\hline Пальне і мастильні матеріали & 1,7 & 5,0 & 6,2 & 8,3 & 8,5 & 3,0 & 4,6 & 5,3 \\
\hline Амортизація необоротних засобів & 2,6 & 1,2 & 3,6 & 0,1 & 0,6 & 0,3 & 4,1 & 1,8 \\
\hline Решта матеріальних витрат & 12,8 & 10,4 & 7,4 & 1,8 & 10,4 & 20,6 & 0,7 & 9,2 \\
\hline $\begin{array}{l}\text { Оплата послуг і робіт сторонніх } \\
\text { організацій }\end{array}$ & 0,7 & - & - & - & 5,0 & 13,0 & 2,2 & 3,0 \\
\hline $\begin{array}{l}\text { Решта інших прямих та загально- } \\
\text { виробничих витрат }\end{array}$ & 5,2 & 2,0 & 6,9 & 0,5 & 1,4 & 1,2 & 1,7 & 2,7 \\
\hline
\end{tabular}

Джерело: розраховано автором на даних державних підприємств «Дослідне господарство «Нива» та «Дослідне господарство «Христинівське» Інституту розведення і генетики тварин імені М. В. Зубия НААН (Черкаська обл.)

Результати аналізу непродуктивних витрат на виробництво продукції молочного скотарства в дослідних господарствах Інституту розведення і генетики тварин імені М. В. Зубця НААН засвідчила, що рівень витрат кормів з розрахунку на одиницю продукції в натуральному вимірі наближається до норми, проте у 2014 році виникали непродуктивні витрати від перевитрат кормів у розмірі 54-91 грн. із розрахунку на 1 корову. Затрати праці на виробництво молока в обох господарствах практично не перевищували нормативні, хоч в дослідному господарстві «Нива» у 2014-2015 роках виникали непродуктивні витрати у розмірі 38 тис. грн. Економічних втрат від нееквівалентних цін реалізації молока у порівнянні із середніми по регіону за вказаний період господарства не зазнавали.

Відповідно до аналізу показників відтворення поголів'я худоби господарств, виявлено збільшення тривалості сервіс-періоду до 132 днів у дослідному господарстві «Христинівське» у 2014 році, внаслідок чого непродуктивні витрати склали 8,3 тис. грн. Всього обсяг непродуктивних витрат у молочному скотарстві державних підприємств «Дослідне господарство «Нива» та «Дослідне господарство «Христинівське» Інституту розведення і генетики тварин імені М. В. Зубця НААН у 2014 році становили відповідно 49,9 та 50,6 тис. грн., або 114,7 та 144,5 грн. $з$ розрахунку на одну корову. Загалом, внаслідок порушень технології утримання корів частка непродуктивних витрат у 2014 році склала близько 2 \% витрат на виробництво молока.

3 метою підвищення ефективності виробничих процесів молочного скотарства державних підприємств «Дослідне господарство «Нива» та «Дослідне господарство «Христинівське» Інституту розведення і генетики тварин імені М. В. Зубця НААН, збільшення фінансових надходжень від реалізації продукції шляхом покращення кількісних та якісних показників продуктивності тварин, зниження рівня непродуктивних витрат з 2015 року запроваджено науковий супровід виробничогосподарської діяльності господарств фахівцями інституту із селекції, генетики, відтворення та годівлі. Співробітники інституту разом з фахівцями дослідних господарств виконували практичні роботи з підвищення відтворної здатності маточного поголів'я великої рогатої худоби, проведення експертної оцінки екстер'єру корів-первісток та розробки індивідуального плану підбору бугаїв і телиць, автоматизованого балансування раціонів худоби, оцінки якості молока та діагностики 
субклінічних маститів, запровадження елементів технологічної схеми сучасної системи ведення племінного обліку і реєстрації тварин та системи контролю реєстрації облікових показників комп'ютерної системи ведення племінного обліку. Проводяться роботи із оцінки та корекції статевої функції телиць для підвищення ефективності трансплантації ембріонів та штучного осіменіння. На основі проведеного селекційно-генетичного моніторингу структури молочного стада господарств за генами кількісних ознак удосконалено генетичну структуру стада.

Комплексна програма впровадження інноваційних розробок у виробничих процесах дослідних господарств також включає проведення економічної оцінки ефективності впровадження інноваційних розробок науковців інституту в практику господарювання дослідних господарств. На першому етапі виконання завдань Комплексної програми (2015 рік) відповідно до затвердженої методики [20, 21] було проведено зоотехнічну і економічну оцінку рівня інтенсифікації галузі скотарства дослідних господарств, визначено ефективність використання земельних, трудових, біологічних і фінансових ресурсів за 2012-2014 роки, запропоновано напрями удосконалення механізму формування оплати праці. 32016 року проводиться оперативний аналіз показників виробничо-господарської діяльності з метою виявлення резервів підвищення ефективності галузі молочного скотарства.

Аналіз ефективності використання земельних, трудових, біологічних і фінансових ресурсів за 2014-2017 роки засвідчив, що за період інноваційно-виробничої співпраці значно зросли кількісні та якісні показники розвитку тваринництва та рослинництва дослідних господарств [22]. Зокрема, за період 2014-2017 років господарства збільшили поголів'я великої рогатої худоби на 44 гол. до 2075 гол., дійного стада - до 850 гол., на 70 гол. (+9 \%). Станом на 1 січня 2018 р. в державному підприємстві «Дослідне господарство «Нива» утримувалось 1212 гол. великої рогатої худоби, у т.ч. 500 корів, у господарстві «Христинівське» - 863 гол., у т.ч. 350 корів.

Молочна продуктивність корів в державному підприємстві «Дослідне господарство «Нива» у 2017 році склала 6711 кг з розрахунку на 1 голову, що на 197 кг молока більше порівняно з минулим роком. За 2014-2017 роки в господарстві збільшено на 5692 ц (+22 \%) виробництво молока. Прибуток від реалізації продукції тваринництва господарства у 2017 р. склав майже 2,2 млн. грн., або 91,1 тис. грн. у розрахунку на 100 га сільськогосподарських угідь, рентабельність становила 12 \%. За результатами збирання зернових культур у господарстві в 2017 році обмолочено 1146 га, валовий збір склав 6,7 тис. т. Середня врожайність зернових культур становила 58,8 ц/га. 3 розрахунку на один гектар площі зібрано: озимої пшениці - 51,4 ц; озимого та ярого ячменю відповідно 66,9 та 52,9 ц; соняшнику - 28,1 ц; кукурудзи на зерно - 96,4 ц.

За 2017 році у державному підприємстві «Дослідне господарство «Христинівське» продуктивність дійного стада зросла на 321 кг до 6832 кг. У порівнянні з 2014 роком обсяг виробленого молока зріс на 2008 ц (+9,2 \%). Прибуток від реалізації молока господарства за 2017 рік становив 429,0 тис. грн., або 27,9 тис. грн. у розрахунку на 100 га сільськогосподарських угідь, рентабельність - 2,5\%. За результатами збирання сільськогосподарських культур в 2017 р. у господарстві обмолочено 695 га, валовий збір склав більше 4,4 тис. т. Середня врожайність зернових культур становила 62,8 ц/га. 3 розрахунку на один гектар площі зібрано: озимої пшениці 51,3 ц; ярого ячменю - 51,4 ц; сої - 16,2 ц; соняшнику - 27,3 ц; кукурудзи на зерно - 86,2.

За рахунок впровадження інноваційних розробок науковців Інституту розведення і генетики тварин імені М. В. Зубця НААН у виробничу діяльність державних підприємств «Дослідне господарство «Нива» та «Дослідне господарство «Христинівське» створено підґрунтя для підвищення їх ефективності на основі інтенсифікації. Зокрема, у 2018 році в дослідних господарствах урожайність зернових культур очікується на рівні 60,5-64,5 ц/га, зростання продуктивності корів до 6880 кг молока на голову за рік, середньодобового приросту живої маси великої рогатої худоби до 645-700 г. Питому вагу непродуктивних витрат в загальному обсязі виробничих витрат молочного скотарства планується скоротити до 0,5 \%. 


\section{Висновки та перспективи.}

До непродуктивних витрат відносять витрати, що мають відхилення у порівнянні із нормативними, що не були відображені у кошторисі. Вони виникають внаслідок незапланованих організаційних причин, порушень технології виробництва, договірних відносин. Причини та динаміка їх виникнення мають бути об'єктом прискіпливого вивчення управлінського обліку та фрінансового менеджменту підприємств.

Непродуктивні витрати в молочному скотарстві виникають від незбалансованої годівлі, неефективного способу утримання, недостатнього догляду та ветеринарного забезпечення, зниження генетичного потенціалу, подовження тривалості міжотельного періоду, скорочення тривалості господарського використання корів, низької якості молока та нееквівалентних цін його реалізації.

Аналіз непродуктивних витрат на утримання великої рогатої худоби молочного напрямку продуктивності, що утримується суб'єктами господарювання, необхідно здійснювати на основі критеріїв, що враховують основні фактори впливу на ефективність. До таких критеріїв відносять інноваційно-виробничі, ринкові, соціально-екологічні.

Відповідно до запропонованих підходів проведено економічну оцінку непродуктивних витрат на виробництво продукції молочного скотарства в державних підприємствах «Дослідне господарство «Нива» та «Дослідне господарство «Христинівське», що входять до мережі Інституту розведення і генетики тварин імені М. В. Зубця НААН (Черкаська обл.), частка яких склала близько $2 \%$ від витрат на виробництво молока. Для оптимізації виробничих витрат підприємств галузі молочного скотарства шляхом зниження рівня непродуктивних витрат на утримання великої рогатої худоби молочного напрямку продуктивності необхідно впровадження комплексу заходів із селекції, генетики, відтворення та годівлі тварин.

\section{Список використаних джерел}

1. Верланов Ю. Фінансовий менеджмент. Миколаїв, 2006. 344 с.

2. Андрійчук В. Г. Економіка підприємств агропромислового комплексу : підручник. Київ : КНЕУ, 2013. 779 c.

3. Андрійчук В. Г. Ефективність діяльності аграрних підприємств : теорія, методика, аналіз : монографія, 2-е вид. без змін. Київ : КНЕУ, 2006. 292 с.

4. Березівський П. С., Ліпич Л. Г., Ющишина Л. О. Оптимізація бізнес-процесів як чинник зниження витрат виробництва. Моделювання регіональної економіки. 2011. № 1. С. 75-82.

5. Березівський П. С. Впровадження внутрішньогосподарських організаційно-економічних механізмів забезпечення прибутковості сільськогосподарських підприємств. Економіка АПК. 2008. № 10. С. 52-54.

6. Дем'яненко С. І. Менеджмент виробничих витрат у сільському господарстві. Київ : КНЕУ, 1998. 264 c.

7. Дієсперов, В. С. Ефективність виробництва сільськогосподарського підприємстві: монографія. Київ : HHЦ«IAE», 2008. $340 \mathrm{C}$.

8. Месель-Веселяк В. Я. Підвищення ефективності сільськогосподарського виробництва. Економіка АПК. 2005. № 6. С. 17-26.

9. Нормативна собівартість та ціни на сільськогосподарську продукцію: в 2-х т. / [За ред. П. Т. Саблука, Ю. Ф. Мельника, М. В. Зубця, В. Я. Месель-Веселяка]. Київ : ННЦ IAE, 2008. Т. 2. Ціноутворення та нормативні витрати в сільському господарстві (теорія, методологія, практика). 2008. 650 с.

10. Економіка виробництва молока і молочної продукції в Україні : монографрія / П.Т. Саблук, В.І. Бойко, Т.Л. Мостенська та ін. ; за ред. П. Т. Саблука і В. І. Бойка. Київ : ННЦ IAE, 2005. 340 с.

11. Саблук П. Т. Проблеми забезпечення дохідності агропромислового виробництва в Україні в постіндустріальний період. Економіка АПК. 2008. № 4. С. 19-37.

12. Шиян Д.В., Ульянченко Н.В. Ефективність витрат у сільськогосподарських підприємствах : монографія. Харків : Міськдрук, 2012. 204 с.

13. Матюшина Ю. Класифікація витрат як передумова організації управління підприємством. Економіка і регіон. 2013. № 2 (39). С. 98-103.

14. Методичні рекомендації з планування, обліку і калькулювання собівартості продукції (робіт, послуг) 
сільськогосподарських підприємств, затверджені Наказом Міністерства аграрної політики України від 18 травня 2001 року № 132.

15. Лень В. С., Мисік В. С. Непродуктивні витрати в обліку та звітності. Вісник Черн. держ. техн. унmy. 2008. № 33. С. 29-38.

16. Тивончук Я. О. Сучасні тенденції конкурентоспроможного розвитку ринку молока і молокопродуктів у Франції. Економіка АПК. 2011. № 1. С. 169-175.

17. Чуйко Н. В. Ефективність виробництва молока при різних способах утримання корів. Вісник ХНАУ. 2010. № 11. С. 176-180.

18. Фичак В. Програма оцінки тварин за МЕП уже працює в Україні. Агроексперт. 2011. № 9. С. 92-93.

19. Афранасєвич М. Азбука молочної ферми. Агроексперт. 2011. № 8. С. 95-99.

20. Система моніторингу раціонального використання виробничих і фінансових ресурсів та удосконалення механізму формування оплати праці Державного підприємства «Дослідне господарство «Нива» в умовах економічної кризи : методичні рекомендації / П. І. Шаран, М. Г. Порхун, І. С. Мартинюк, Н. М. Коваленко, О. В. Кругляк, А. Є. Почукалін ; наукова редакція доктора економічних наук, професора, академіка НААН М. В. Гладія. Чубинське, 2014. 40 с.

21. Система моніторингу раціонального використання виробничих і фінансових ресурсів та удосконалення механізму формування оплати праці Державного підприємства «Дослідне господарство «Христинівське» в умовах економічної кризи : методичні рекомендації / П. І. Шаран, М. Г. Порхун, І. С. Мартинюк, Н. М. Коваленко, О.В.Кругляк, А. Є. Почукалін ; наукова редакція доктора економічних наук, профессора, академіка НААН М. В. Гладія. Чубинське, 2014. 40 с.

22. Науково-експериментальна база Інституту розведення і генетики тварин імені М.В.Зубця НААН в умовах ринкових відносин / М. Я. Єфіменко, М. В. Гладій, О. В. Кругляк, П. І. Шаран, Ю. П. Полупан, С. І. Ковтун, М. Г. Порхун, Л. В. Мітіогло, М. М. Передрій ; за редакцією академіка НААН М. В. Гладія, Чубинське, 2017. 41 c. Retrivied from http://iabg.org.ua/images/stories/IRGT-dosvid_OST.pdf (дата звернення: 08.03.2018).

Статтю отримано: 25.03.2018 Рецензування 25.04.2018 Прийнято до друку: 15.05.2018

\author{
Olga Kruglyak \\ $\mathrm{PhD}$ (in Economics), Senior Research Fellow, Leading Research Fellow \\ Laboratory of Genetic Resources and Experimental Farms \\ Institute of Animal Breeding and Genetics nd. a. M.V.Zubets of NAAS \\ Chubynske, Ukraine \\ E-mail: ovokrug@gmail.com \\ ECONOMIC EVALUATION UNPRODUCTIVE COSTS FOR DAIRY CATTLE \\ MAINTENANCE
}

\begin{abstract}
Introduction. The study is devoted to the analytical interpretation of non-productive expenditures in animal husbandry, in particular, in dairy cattle breeding and the search for ways to reduce the level of unproductive expenditures on the maintenance of dairy cattle.

Methodology. Created by the author database on the economic indicators of the activities of state enterprises of Cherkasy region, included in the network of the M. Zubts Institute of Animal Breeding and Genetics of the National Academy of Agrarian Sciences of Ukraine served as the research information base. In the process of research, methods of content analysis of scientific sources and legal documents, structural analysis and comparison, statistical and economicmathematical methods were used to systematization, classification and analytical interpretation of non-productive livestock in general, and dairy cattle breeding, in particular.

Results. As a result of the studies, the classification of expenses by efficiency in dairy cattle breeding was carried out. The research results showed that the analysis of non-productive expenditures on the maintenance of dairy cattle is reasonable to carry out on the basis of a criteria set, such as: innovation and production, market, social and environmental. In accordance with the proposed approaches, an analytical interpretation of the unproductive expenditures on the production of dairy cattle breeding in state enterprises belonging to the network of the Institute of Animal Breeding and Genetics named after MV Zubts NAAN (Cherkasy region) has been carried out. Their share was about $2 \%$ of the total cost of milk production.

The following hypothesis was confirmed - unproductive costs in dairy cattle breeding arise from unbalanced feeding, inefficient maintenance, insufficient care and veterinary care, reduced genetic potential, increased duration of the mihotal
\end{abstract}


period, reduced duration of economic use of cows, poor quality milk and inequivalent prices for its implementation.

Findings. According to the research, it was concluded that the proposed measures to optimize the production costs of enterprises of the dairy cattle breeding industry by reducing the level of unproductive expenditures on the maintenance of dairy productivity cattle are possible with the introduction of measures set for animals breeding, genetics, reproduction and feeding.

Keywords: production costs, analysis, cost management, overhead, dairy cattle, efficiency.

\section{References}

1. Verlanov, Yu. 2006. Finansovyy menedzhment [Financial Management]. Mykolaiv [in Ukrainian].

2. Andriichuk, V. H. (2013). Ekonomika pidpryiemstv ahropromyslovoho kompleksu [The economy of enterprises of the agro-industrial complex]. Kyiv : KNEU. [in Ukrainian].

3. Andriichuk, V. H. (2006). Efektyvnist diialnosti ahrarnykh pidpryiemstv : teoriia, metodyka, analiz [Efficiency of the activities of agrarian enterprises: theory, methodology, analysis (2-nd ed)]. Kyiv : KNEU. [in Ukrainian].

4. Berezivskyi, P. S., Lipych, L. H., \& Yushchyshyna, L. O. (2011). Optymizatsiia biznes-protsesiv yak chynnyk znyzhennia vytrat vyrobnytstva [Optimization of business processes as a factor in reducing production costs]. Modeliuvannia rehionalnoi ekonomiky, 1, 75-82. [in Ukrainian].

5. Berezivskyi, P. S. (2008). Vprovadzhennia vnutrishnohospodarskykh orhanizatsiino-ekonomichnykh mekhanizmiv zabezpechennia prybutkovosti silskohospodarskykh pidpryiemstv [Introduction of intraeconomic organizational and economic mechanisms to ensure the profitability of agricultural enterprises]. Ekonomika APK, 10, 52-54. [in Ukrainian].

6. Demianenko, S. I. (1998). Menedzhment vyrobnychykh vytrat u silskomu hospodarstvi [Management of production costs in agriculture]. Kyiv : KNEU. [in Ukrainian].

7. Diiesperov, V. S. (2008). Efektyvnist vyrobnytstva silskohospodarskoho pidpryiemstvi [The effectiveness of agricultural production enterprise monograph]. Kyiv : NNTs «IAE». [in Ukrainian].

8. Mesel-Veseliak, V. Ya. (2005). Pidvyshchennia efektyvnosti silskohospodarskoho vyrobnytstva [Improving the efficiency of agricultural production. Economy of agroindustrial complex]. Ekonomika APK, 2005. № 6. S. 17-26. [in Ukrainian].

9. Sabluk, P. T., Melnyk, Yu. F., Zubets, M. V., \& Mesel-Veseliak, V. Ya. (Eds.) (2008). Normatyvna sobivartist ta tsiny na silskohospodarsku produktsiiu : $v$ 2-kh $t$. Is. 2. Tsinoutvorennia ta normatyvni vytraty $v$ silskomu hospodarstvi (teoriia, metodolohiia, praktyka) [Regulatory costs and prices for agricultural products: in 2 parts, P. 2. Pricing and standard costs in agriculture (theory, methodology, practice)]. Kyiv : NNTs IAE. [in Ukrainian].

10. Sabluk, P.T., \& Boiko, V.I. (Eds.) (2005). Ekonomika vyrobnytstva moloka i molochnoi produktsii v Ukraini [The economy of milk and dairy production in Ukraine]. Kyiv : NNTs IAE. [in Ukrainian].

11. Sabluk P. T. (2008). Problemy zabezpechennia dokhidnosti ahropromyslovoho vyrobnytstva v Ukraini $v$ postindustrialnyi period [Problems of ensuring the profitability of agro-industrial production in Ukraine in the postindustrial period. Economy of agroindustrial complex]. Ekonomika APK, 4, 19-37. [in Ukrainian].

12. Shyian, D. V., \& Ulianchenko, N. V. (2012). Efektyvnist vytrat u silskohospodarskykh pidpryiemstvakh [Efficiency of costs in agricultural enterprises]. Kharkiv [in Ukrainian].

13. Matiushyna, Yu. (2013). Klasyfikatsiia vytrat yak peredumova orhanizatsii upravlinnia pidpryiemstvom [Classification of costs as a prerequisite for the organization of enterprise management]. Ekonomika i rehion, 2 (39), 98-103. [in Ukrainian].

14. Metodychni rekomendatsii z planuvannia, obliku i kalkuliuvannia sobivartosti produktsii (robit, posluh) silskohospodarskykh pidpryiemstv, zatverdzheni Nakazom Ministerstva ahrarnoi polityky Ukrainy vid 18 travnia 2001 roku № 132 [Methodical recommendations on planning, accounting and costing of production costs (works, services) of agricultural enterprises approved by the Order of the Ministry of Agrarian Policy of Ukraine of May 18, 2001 No. 132]. [in Ukrainian].

15. Len, V. S., \& Mysik, V. S. (2008). Neproduktyvni vytraty v obliku ta zvitnosti [Unproductive expenses in accounting and reporting.]. Visnyk Chern. derzh. tekhn. un-tu, 33, 29-38. [in Ukrainian].

16. Tyvonchuk, Ya. O. (2011). Suchasni tendentsii konkurentospromozhnoho rozvytku rynku moloka i molokoproduktiv u Frantsii [Modern trends in the competitive development of the milk and dairy products market in France]. Ekonomika APK, 1, 169-175. [in Ukrainian].

17. Chuiko, N. V. (2010). Efektyvnist vyrobnytstva moloka pry riznykh sposobakh utrymannia koriv [Efficiency of milk production in different ways of keeping cows]. Visnyk KhNAU, 11, 176-180.

18. Fychak, V. (2009). Prohrama otsinky tvaryn za MEP uzhe pratsiuie v Ukraini [Animal Assessment Program for MEP already works in Ukraine]. Ahroekspert, 9, 92-93. [in Ukrainian]. 
19. Afanasievych, M. (2011). Azbuka molochnoi fermy [The ABC of a dairy farm]. Ahroekspert, 8, 95-99. [in Ukrainian].

20. Sharan, P. I. Porkhun, M. H., Martyniuk, I. S., Kovalenko, N. M., Kruhliak, O. V., \& Pochukalin, A. Ye. (2014). Systema monitorynhu ratsionalnoho vykorystannia vyrobnychykh $i$ finansovykh resursiv ta udoskonalennia mekhanizmu formuvannia oplaty pratsi Derzhavnoho pidpryiemstva "Doslidne hospodarstvo «Nyva» v umovakh ekonomichnoi kryzy : metodychni rekomendatsii [Monitoring the rational use of production and financial resources and improving the mechanism for forming the remuneration of the State Enterprise "Experimental Farm" Niva "in the conditions of the economic crisis: methodological recommendations]. Chubynske. [in Ukrainian].

21. Sharan, P. I., Porkhun, M. H., Martyniuk, I. S., Kovalenko, N. M., Kruhliak, O. V., \& Pochukalin, A. Ye. (2014). Systema monitorynhu ratsionalnoho vykorystannia vyrobnychykh i finansovykh resursiv ta udoskonalennia mekhanizmu formuvannia oplaty pratsi Derzhavnoho pidpryiemstva «Doslidne hospodarstvo «Khrystynivske» v umovakh ekonomichnoi kryzy : metodychni rekomendatsii [The monitoring system for the rational use of production and financial resources and the improvement of the mechanism for forming the remuneration of the state enterprise "Experimental farm" Khristinovskoye "in the conditions of the economic crisis: methodological recommendations]. Chubynske. [in Ukrainian].

22. Yefimenko, M. Ya., Hladii, M. V., Kruhliak, O. V., Sharan, P. I., Polupan, Yu. P. S. Porkhun, ... \& Peredrii, M. M. (2017). Naukovo-eksperymentalna baza Instytutu rozvedennia i henetyky tvaryn imeni M.V.Zubtsia NAAN v umovakh rynkovykh vidnosyn [Scientific and experimental base of the Institute of Animal Breeding and Genetics named after MVZubtsya of the National Academy of Sciences in the conditions of market relations]. Chubynske. Retrivied from http://iabg.org.ua/images/stories/IRGT-dosvid_OST.pdf [in Ukrainian].

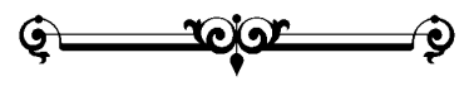

